\title{
L

\section{Refleksi Teologis Kitab Hosea Tentang Peran Tuhan Terhadap Kekudusan}

\author{
Paulus Kunto Baskoro \\ Sekolah Tinggi Teologi Anugerah Allianse Semarang - Surakarta \\ paulusbaskoro1177@gmail.com
}

\begin{abstract}
Holiness is a very serious matter before God and is not compromised at any price. Holiness is the most important part of a relationship between God and humans. However, it cannot be denied that because of sin, the quality of human holiness with God is destroyed. God cannot compromise sin. Sin severed man's relationship with God. Seeing how very important holiness is, it is necessary to seriously discuss the meaning of holiness before God. Because what is happening at this time, holiness has begun to fade with evidence of moral destruction and several principles of good life in the family, dating style, service standards and even in work, holiness is not a priority, because holiness remains the highest standard. Through descriptive qualitative method with literature study approach, it can be concluded that in order for people to believe in returning to the divine quality of life, that is, living in holiness according to God's heart. The book of Hosea becomes a reference for serious contemplation with the meaning of a holiness from the side of God's role. And the discussion of this context will focus on the theological understanding of the Book of Hosea by using the method of extracting literature and several sources of writings that strongly strengthen the theological concept. So that from exploring the theological concepts of God's role in the holiness of the Book of Hosea, we can get a reflection of life that holiness is the most important part in the standard of life forever.
\end{abstract}

Keywords : The Book of Hosea, God's Role, Holiness.

\begin{abstract}
Abstrak
Kekudusan menjadi hal yang sangat serius di hadapan Tuhan dan tidak ada ditawar-tawar dengan harga apapun. Kekudusan menjadi bagian terpenting bagi sebuah hubungan antara Tuhan dengan manusia. Namun tidak bisa dipungkiri, karena dosa, maka kualitas kekudusan manusia dengan Allah menjadi hancur. Allah tidak bisa kompromi dengan dosa. Dosa membuat hubungan manusia dengan Allah menjadi terputus. Melihat betapa sangat pentingnya kekudusan, maka perlu dibahas secara serius arti sebuah kekudusan di hadapan Allah. Sebab yang terjadi saat ini, kekudusan sudah mulai luntur dengan terbuktinya kehancuran moral dan beberapa prinsip-prinsip kehidupan baik dalam keluarga, gaya pacaran, standar pelayanan bahkan dalam pekerjaan, kekudusan menjadi hal yang tidak diutamakan, sebab kekudusan tetap menjadi standar tertinggi. Melalui metode kualitatif deskriptif dengan pendekatan studi pustaka dapat disimpulkan bahwa supaya orang percaya kembali kepada kualitas hidup ilahi, yaitu hidup dalam kekudusan sesuai dengan hati Tuhan. Kitab Hosea menjadi acuan untuk perenungan secara serius dengan arti sebuah kekudusan dari sisi peran Tuhan. Dan pembahasan konteks ini akan difokuskan kepada pemahaman teologis dari Kitab Hosea dengan menggunakan metode penggalian pustaka dan beberapa sumber penulisan-penulisan yang sangat menguatkan konsep teologisnya. Sehingga dari
\end{abstract}


penggalian konsep-kosep teologis peran Tuhan dalam kekudusan dari Kitab Hosea, didapatkan refleksi kehidupan bahwa kekudusan menjadi bagian terpenting dalam standar kehidupan sampai selamalamanya.

\section{Kata kunci : Kitab Hosea, Peran Tuhan, Kekudusan}

\section{PENDAHULUAN}

Kekudusan menjadi bagian terpenting serta kursial dalam sepanjang standar kehidupan, namun tidak bisa disangkali, dapat dilihat bahwa kekudusan menjadi sebuah hal yang murahan. Allah tidak pernah menurunkan standar dalam membangun sebuah hubungan. Kekudusan menjadi standar tertinggi Allah dalam membangun sebuah hubungan. Seperti dinyatakan dalam kebenaran Firman Tuhan, dalam 1 Petrus 1:16, "sebab ada tertulis: Kuduslah kamu, sebab Aku kudus." Artinya standar kekudusan manusia juga sesuai dengan kekudusan Tuhan. Dosa yang membuat kekudusan manusia menjadi hancur berantakan dan menjadi hubungan Allah dengan manusia terputus, sehingga manusia menjadi pribadi yang jauh dari Allah. Sebab dosa adalah melanggar perintah Tuhan dan mengakibatkan sakit hati Tuhan (Tarpin, 2010). Kekudusan dalam masa sekarang ini menjadi sesuatu Standard kehidupan yang langka. Bahkan sudah tidak menjadi perhatian khusus dalam berbagai sisi kehidupan.

Dari perenungan ini, dapat dilihat contoh yang paling nyata, yaitu bangsa Israel. Diaman Allah sudah sangat mengasihi bangsa ini, sampai bagi Allah, bangsa Israel merupakan biji mata Allah. Namun dalam perjalanan kehidupan bangsa Israel mengalami banyak jatuh bangun dalam dosa, baik itu dosa berbuat jahat, bersungut-sungut, berbuat zinah, mencuri, membunuh, menyembah berhala bahkan dengan sengaja membuat patung-patung berhala untuk disembah. Kekudusan menjadi hal yang sudah tidak dipertahankan oleh bangsa Israel. Padahal jika bangsa Israel bertobat, Allah mengampuni (Lele \& Panggarra, 2015). Allah dengan berbagai macam cara berbicara baik melewat nabi-nabi, hakim-hakim, raja-raja, imam-imam untuk Israel bertobat, namun tetap Israel tidak mengalami pertobatan. Padahal kasih Allah kepada bangsa Israel luar biasa (Marbun, 2020). Beberapa kali setiap bangsa Israel berbuat dosa, melanggar kekudusan Allah, mereka diserahkan kepada tindasan bangsa-bangsa lain, namun tetap saja, bangsa Israel tidak bertobat. Memang terkadang, ketika hakim-hakim memerintah, Israel bertobat dan kembali menyembah Allah yang benar, namun ketika pemimpin mereka mati, bangsa Israel jatuh kembali dalam dosa. Bahkan akhirnya, Tuhan harus membuang bangsa Israel ke Babel dan Asyur, sebab mereka tidak hidup sesuai dengan standar Tuhan. Dan inilah yang menjadi pesan khusus dalam Perjanjian Lama, dengan ditaruhnya Tuhan, nabi-nabi dalam masa pembuangan (Simbawa, 2010).

Dalam masa pembuangan, Nabi Hosea hadir untuk memberikan peringatan-peringatan. Bahkan Tuhan sendiri menggunakan contoh hidup dari Hosea untuk mengingatkan betapa bangsa Israel sudah melanggar kekudusan, dengan hidup dalam penyembahan berhala, yang membuat sakit hati Tuhan. Peran Tuhan dalam kehidupan Hosea dan Gomer inilah yang akan menjadi acuan untuk bisa memahami konsep teologis tentang kekudusan dari Kitab Hosea, (Hutagalung, 2019) yang akan menjadi refleksi bagi kehidupan orang percaya masa kini dengan menjadi kekudusan sebagai bagian moral penting yang tidak bisa digeser dengan standar apapun dalam kehidupan ini. Sehingga perkenanan Tuhan senantiasa nyata dalam kehidupan orang percaya, nama Tuhan dipermuliakan dan akan muncul generasi-generasi ilahi. 
Penelitian ini menggunakan metode deskritif, (Zaluchu, 2020) yaitu mempelajari tentang konsep-konsep teologi dari Kitab Hosea tentang peran Tuhan dalam kekudusan. Dengan menggunakan metode penggalian dari berbagai sumber pustaka yang ada, serta penulisanpenulisan dari berbagai sumber. Sehingga dapat dipahami bahwa kekudusan menjadi hal yang sangat serius dalam kehidupan serta hubungan Tuhan dengan manusia. Kemudian dari setiap konsep teologis peran Tuhan dalam kekudusan dari Kitab Hosea yang sudah didapatkan, direfleksikan dalam kehidupan masa kini. Untuk dijadikan acuan kuat bahwa kekudusan menjadi hal yang harus terus dijaga dan dipertahankan dalam masa dan kondisi apapun dan ini merupakan ciri manusia baru (Darius \& Panggarra, 2013).

\section{PEMBAHASAN Landasan Dasar Kitab Hosea}

Memahami Kitab Hosea sangat penting untuk mengerti secara utuh kerangka pikir yang ada di dalamnya, sehingga bisa diambil beberapa kesimpulan konsep teologinya. Kitab Hosea menjadi salah satu Kitab yang unik dalam pembahasannya, khusus dalam kehidupan nabi Hosea, sebagai ilustrasi bagi hubungan Allah dan bangsa Israel (Setio, 2017). Banyak hal-hal yang sangat penting untuk direnungkan, karena memiliki muatan teologis yang sangat dalam, sehingga sebagai orang percaya dapat melihat betapa kasih Tuhan yang sangat luar biasa bagi seluruh umat manusia. Beberapa bagian yang ada dikaji dalam landasan dasar Kitab Hosea yaitu penulis kitab, tahun penulian kitab, tujuan kitab, latar belakang kitab dan garis besar kitab.

\section{Latar belakang dan Garis besar kitab Hosea}

Kekuatan sebuah kitab juga dilihat dari sisi kehidupan serta kualitas penulis dalam pengilhaman. Kitab Hosea ditulis oleh nabi Hosea sendiri, sebagai penerima pewahyuan tentang kehidupan bangsa Israel, yang dikuatkan juga dengan pendapat beberapa ahli kitab (Alkitab Hidup Berkelimpahan Life Application Study Bible, 2016). Arti Hosea adalah keselamatan, Tuhan adalah penyelamat, keselamatan pada Tuhan. Nama lengkap sesuai marganya adalah Hosea bin Beeri, Beeri adalah nama ayahnya (Hos. 1:1).(Alkitab Hidup Berkelimpahan Life Application Study Bible, 2016) Nabi Hosea juga menjadi tokoh sentral dalam Kitab Hosea, yang menjadi nabi di Israel pada abad 8 SM (785 - 725 SM), yang menempati tempat special dalam Perjanjian Lama (Sudarman, 2017). Di mana nabi Hosea dipakai oleh Tuhan menjadi tokoh pelaku langsung dalam ilustrasi hubungan Allah dengan bangsa Israel, yang mengawini perempuan sundal, bernama Gomer serta menghasilkan 3 anak yaitu Yizreel, Lo-Ruhama dan Lo-Ami. Nabi Hosea hidup pada masa bangsa Israel dibuang ke Babel. Kehidupan bangsa Israel menjadi sebuah moment khusus oleh Tuhan untuk menyampaikan pesan Firman-Nya, supaya bangsa Israel mengalami pertobatan secara sempurna. Bangsa ini termasuk bangsa yang unik, sebab sebagai bangsa pilihan Tuhan, bangsa Israel memiliki sifat tegar tengkuk serta tidak permanen dalam menjaga kekudusan hubungan Allah dengan manusia. Allah berbicara kepada umat-Nya dengan berbagai cara, namun kali ini, dalam Kitab Hosea, Allah berbicara kepada bangsa Israel dengan sebuah ilustrasi langsung dari kehidupan yang dialami oleh nabi Hosea. Sebagai penulis Kitab Hosea, maka nabi Hosea sangat memahami hati Tuhan. Kitab Hosea termasuk dalam golongan kitab nabi-nabi kecil dalam Perjanjian Lama, yang merupakan kitab pertama dalam kitab nabi-nabi kecil.

Penulisan kitab Hosea, terjadi di tahun 715 - 710 SM (Alkitab Hidup Berkelimpahan Life Application Study Bible, 2016). Ditulis oleh Nabi Hosea sendiri dengan sebuah ciri penulisan yang sangat menarik dibandingkan dengan penulis-penulis kitab nabi-nabi yang lain. Hosea menjadi nabi yang menulis seluruh pesan Tuhan kepada bangsa Israel dengan sebuah kehidupan yang nyata. Menarik untuk sangat diperhatikan dan menjadi pembahasan untuk dijadikan pembelajaran. 
Kitab ini menyajikan konsep-konsep teologis yang sangat kuat, pesan yang mendalam bagi kehidupan, pertobatan dan pemulihan bangsa Israel. Kehidupan bangsa Israel menjadi perhatian khusus bagi Allah, supaya bangsa Israel menyadari betapa dalamnya mereka telah jatuh dalam dosa penyembahan berhala, hidup menyimpang dari segala kebenaran Firman Tuhan, tidak setia kepada Tuhan bahkan hidup menjauh dari Tuhan yang telah melakukan banyak hal-hal ajaib. Bahkan dalam kitab Hosea dapat diperhatikan secara menyeluruh, sebuah pesan Allah yang rindu membangun sebuah hubungan kuat dengan bangsa Israel yang telah hancur. Ada 150 pernyataan dosa bangsa Israel di kitab Hosea (Alkitab Hidup Berkelimpahan Life Application Study Bible, 2016). Jadi tujuan-tujuan dari kitab Hosea yaitu : Pertama, wujud kasih Allah yang tak terbatas dan tidak berubah; Kedua, kesetiaan Allah yang tidak berubah atas umat-Nya; Ketiga, penghukuman yang akan terjadi, jika umat-Nya tidak bertobat; Keempat, pertobatan umat-Nya; Kelima, hati Tuhan untuk memulihkan kondisi umat-Nya dengan nubuatan yang disampaikan; Keenam, anugerah Allah yang melimpah atas umat-Nya, tetap menerima umat-Nya dalam kondisi apapun; Ketujuh, ada janji-janji Tuhan yang dinyatakan bagi umat-Nya. Semua tujuan ini terangkum dalam kehidupan nabi Hosea yang dipakai Tuhan menjadi jembatan pemahaman Allah tentang bangsa Israel, yaitu ketidaksetiaan Gomer, isteri Hosea, yang tidak setia kepada Hosea, sebagai suami yang sah. Gambaran ini yang menjadi nilai pengalaman spiritual Hosea melihat hati Tuhan, ketika bangsa Israel tidak setia (Natar, 2016). Gomer yang melakukan perzinahan secara jasmani, sedangkan bangsa Israel melakukan perzinahan rohani dengan menyembah berhala-berhala atau patung-patung, pengganti Allah yang telah melepaskan mereka dari tanah Mesir.

Bangsa Israel adalah bangsa yang sangat dikasihi Tuhan. Namun sebagai bangsa yang sangat dikasihi Tuhan, bangsa Israel menyia-nyiakan kasih karunia itu. Bangsa ini menjadi bangsa yang tegar tengkuk, bangsa yang keras kepala, bangsa yang suka bersungut-sungut, bangsa yang berbuat jahat di hadapan Tuhan, bangsa yang hidup dalam perzinahan dan bangsa yang hidup dalam penyembahan berhala. Akhirnya bangsa Israel pecah menjadi 2 yaitu Kerajaan Utara dan Kerajaan Selatan. Kedua kubu kerajaan ini tidak menunjukkan pertobatan, sehingga dibuang Tuhan baik di Asyur maupun di Babel. Dalam pembuangan, bangsa Israel justru makin jauh dari Tuhan, kesengsaraan dan kemiskinan menjadi bagian mereka. Tuhan dengan berbagai cara memperingatkan dan menyatakan janji-Nya, namun bangsa Israel tidak memperdulikan. Sampai akhirnya nabi Hosea diutus Tuhan untuk menyatakan berita pertobatan dan pemulihan dengan janji Tuhan. Terkhusus dalam pelayanan nabi Hosea bagi Kerajaan Utara. Di tahun $750 \mathrm{SM}$, nabi Hosea mulai memberitakan pesan Tuhan kepada bangsa Israel. Pelayanan Hosea bersamaan dengan nabi Amos dan Yesaya, di sekitar zaman Raja Uzia (781740 SM), Raja Yotam (740-736 SM), Raja Ahas (736-716 SM), dan Raja Hizkia (716-687 SM). Di mana di tahun 722 SM Samaria mengalami kehancuran.

Persundalan rohani, yaitu penyembahan berhala, kehancuran rohani, moral dan politik serta sosial, yang membuat Tuhan dengan kasih-Nya yang tanpa syarat untuk mengingatkan bangsa Israel melewat nabi Hosea dan dalam konteks ini, kehidupan nabi Hosea dan keluarganya menjadi gambaran ketidaksetiaan Israel kepada Allah. Bangsa Israel sudah tidak hidup dalam kekudusan. Allah memerintahkan Hosea untuk menikahi perempuan sundal (Hos. 1:1-29) dan memiliki anak dari perkawinan itu. Ini yang menjadi gambaran bangsa Israel yang memiliki ikatan perjanjian dengan Allah tetap setia dengan kasih-Nya meskipun bangsa Israel sudah jauh dari Tuhan. Namun setelah dinikahi, Gomer, isteri Hosea berbuat zinah dengan mengalih kepada laki-laki lain (Alkitab Hidup Berkelimpahan Life Application Study Bible, 2016). Ini yang menggmbarkan ketidaksetiaan bangsa Israel yang melanggar kekudusan Tuhan dengan beralih kepada penyembahan berhala-hala. Namun Tuhan tetap memberikan pengampunan. Akibatnya, jika mereka tidak bertobat, Tuhan akan membinasakan bangsa Israel.

Garis besar kitab Hosea yaitu tentang perkawinan Hosea dengan seorang wanita sundal yang menggambarkan ketidaksetiaan Israel kepada Allah dan pesan Tuhan kepada bangsa Israel jika mereka tidak bertobat, mereka akan dihancurkan Tuhan. Hubungan Allah dengan Israel 
menjadi tidak baik, sebab bangsa Israel hidup jauh dari kekudusan. Padahal kekudusan menjadi unsur penting dalam sebuah hubungan Allah dengan umat-Nya. Namun Allah tetap menunjukkan kasih-Nya serta pengampunan-Nya yang luar biasa. Tuhan memiliki peran yang sangat penting dalam kehidupan bangsa Israel supaya hidup dalam kekudusan. Dan kitab Hosea masuk dalam golongan kitab nabi-nabi kecil (Alkitab Hidup Berkelimpahan Life Application Study Bible, 2016).

\section{Konsep Teolgois Kitab Hosea Tentang Peran Tuhan Terhadap Kekudusan}

Kondisi bangsa Israel dalam masa pembuangan sangat memprihatinkan. Segala yang terjadi tidak seperti yang diharapkan. Mereka mengalami kemerosotan kerohanian, sosial, ekonomi, karena mereka hidup jauh dari Tuhan. Sebetulnya hati Tuhan, ketika mereka mengalami pembuangan, Tuhan berharap mereka sadar dan bertobat. Namun justru Israel makin hidup menjauh dari Tuhan. Mereka melupakan segala perbuatan ajaib Tuhan yang telah menuntun mereka keluar dari Mesir. Di atas semua yang terjadi atas bangsa Israel, dengan ketidaksetiaannya itu, menjadikan bangsa Israel dalam ketidakkudusan Tuhan. Mereka mengalami perzinahan rohani. Tapi betapa hati Tuhan tetap mengasihi mereka dengan segala cara Allah tunjukkan kepada bangsa Israel. Akhirnya, Allah campur tangan dengan kisah kehidupan nabi Hosea untuk memperlihatkan kondisi keadaan bangsa Israel yang sesungguhnya, yang membuat hati Tuhan hancur.

Beberapa konsep teologis yang muncul dalam kitab Hosea menjadi perenungan untuk melihat betapa peran Tuhan terhadap konsep kekudusan yang diperlihatkan Tuhan kepada bangsa Israel. Konsep teologis ini adalah hati Tuhan bagi bangsa Israel yang telah hidup tidak sesuai dengan Taurat Tuhan. Hidup dalam penyembahan berhala, yang bagi Tuhan ini melanggar kekudusan. Sebab Allah Israel adalah Allah yang cemburu. Keluaran 20:5 Jangan sujud menyembah kepadanya atau beribadah kepadanya, sebab Aku, TUHAN, Allahmu, adalah Allah yang cemburu, yang membalaskan kesalahan bapa kepada anak-anaknya, kepada keturunan yang ketiga dan keempat dari orang-orang yang membenci Aku, Keluaran 34:14 Sebab janganlah engkau sujud menyembah kepada allah lain, karena TUHAN, yang nama-Nya Cemburuan, adalah Allah yang cemburu. Ketidakkudusan bangsa Israel, membuat Tuhan turun tangan untuk membuat bangsa Israel sadar dan bertobat kembali.

\section{Tuhan tidak pernah menurunkan standar kekudusan}

Tuhan sebagai pribadi yang kudus. Kekudusan Tuhan mutlak dan tidak dapat tergantikan dengan apapun dan dalam kondisi apapun. Bangsa Israel yang hidup dalam penyembahan berhala menjadikan hati Tuhan sangat sedih. Firman Tuhan datang kepada Hosea bin Beeri pada zaman Uzia, Yotam, Ahas dan Hizkia, raja-raja Yehuda dan zaman Yerobeam bin Yoas, raja Israel. Israel sedang dalam masa-masa pembuangan. Hidup Israel makin terpuruk dan merosot. Allah sangat mengasihi umat-Nya dengan berfirman melewati nabi Hosea. Keluarga Hosea menjadi gambaran Israel yang melanggar kekudusan Tuhan dengan tidak setia kepada Allah yang membawa mereka keluar dari Mesir. Dalam hal ini peran Tuhan untuk menunjukkan kepada Israel bahwa Allah sangat perduli dengan bangsa-Nya.

Point penting yang mau Allah sampaikan lewat kehidupan keluarga Hosea yang menjadi gambaran kehidupan bangsa Israel yang sudah tidak hidup kudus, yaitu bahwa Tuhan adalah Allah yang tidak pernah menurunkan standar kekudusan dalam bentuk apapun dan situasi apapun. Gambaran yang Allah nyatakan bagi bangsa Israel adalah Tuhan berfirman kepada Hosea untuk pergi mengawini perempuan sundal dan memperanakkan anak-anak sundal (Hos. 1:2-9). Hal ini merupakan gambaran jelas secara fakta nyata bahwa betapa sangat hebat persundalan bangsa Israel, hidup dalam ketidakkudusan dengan menyembah allah-allah lain. Di mana Allah mau memberikan perlambangan bahwa Hosea sebagai pribadi Allah dan perempuan sundal sebagai bangsa Israel yang sudah hidup tidak kudus. Hosea pergi sesuai dengan perintah 
Tuhan dengan mengawini perempuan sundal yang bernama Gomer binti Diblaim dan melahirkan 3 anak laki-laki dari hasil hubungan mereka. Anak pertama, Yizreel yang berarti Tuhan akan menghukum keluarga Yehu karena hutang darah Yizreel dan mengasihi pemerintahan bangsa Israel (Hos. 1:3-4). Anak kedua bernama Lo-Ruhama yang berarti bahwa Allah tidak akan menyayangi lagi bangsa Israel serta sama sekali tidak mengampuni dosa mereka (Hos. 1:6). Anak ketiga bernama Lo-Ami yang berarti Israel bukan lagi umat Allah dan Tuhan bukan lagi menjadi Allah mereka. Ketiga nama anak Hosea dan Gomer ini menandakan bahwa Tuhan sangat serius dengan kekudusan dan Tuhan tidak menurunkan standar kekudusan dalam bentuk apapun. Kisah ini adalah kisah fakta di mana Tuhan memiliki peran penting untuk menjadi keluarga Hosea, keluarga nabi sebagai gambaran bangsa Israel sehingga muda nabi untuk menyampaikan pesan profetik Tuhan.

\section{Tuhan sanggup melakukan banyak hal untuk umat-Nya fokus kepada Taurat-Nya}

Hati Tuhan, dengan gambaran kehidupan keluarga Hosea, Di mana Hosea sebagai seorang nabi yang hidup benar di hadapan Tuhan, disuruh Tuhan mengawini Gomer, perempuan sundal yang hidup dengan dosa ketidakkudusan, mau menyatakan kepada bangsa Israel dengan harapan Israel dapat melihat kebaikan Tuhan yang berlimpah untuk hidup mentaati Firman Tuhan. Tuhan yang suci dan kudus, sering dinodai dengan hubungan tidak kudus, karena umatNya yang menyembah berhala serta patung-patung buatan bangsa-bangsa lain. Peran Tuhan yang sangat penting dalam point ini adalah Tuhan mendorong supaya umat Israel hidup sesuai dengan kebenaran Firman Tuhan, Karena sejatinya Alkitab sebagai dasar fondasi kerohanian orang percaya,(Arifianto, 2020b) hidup sesuai dengan caranya sendiri, membuat hidup bangsa Israel makin jauh dari Allah. Dengan melihat kebaikan Allah yang luar biasa, maka seharusnya Israel menyadari bahwa jika tanpa Tuhan, maka semuanya tidak mungkin terjadi. Hosea yang hidup benar, bisa mengambil perempuan sundal karena perintah Tuhan kepada diri-Nya. Sehingga gambaran ini mau menyatakan ketika bangsa Israel fokus dalam mentaati kebenaran Firman Tuhan sebetulnya bisa. Jika dipikir secara akal sehat, apa yang terjadi pada hidup Hosea bukanlah yang mudah. Mengambil dan mengawini perempuan sundal, yaitu perempuan yang sudah tidak kudus, merupakan aib besar, sebuah penghakiman sosial dan yang pasti menjadikan hidup juga tidak dalam kekudusan.

Sebetulnya setiap perintah Tuhan tidak sulit dilakukan. Taurat Tuhan dalam Keluaran 20 menjadi acuan hidup bangsa Israel dan sebetulnya mudah untuk dilakukan, asal bangsa Israel dapat fokus untuk melakukan dengan kesungguhan dan tidak menyimpang ke kanan atau ke kiri. Kehidupan bangsa Israel yang tergoda dengan cara hidup bangsa-bangsa asing itulah menjadikan bangsa Israel menjadi makin jauh dari Tuhan. Ketidaktaatan bangsa Israel yang menjadikan Taurat sulit untuk melakukan Taurat dan ini melanggar kekudusan Tuhan. Terutama perintah Taurat no 1-3. Tuhan harus hadir dengan gambaran kehidupan Hosea untuk mengingatkan kembali bahwa Hosea yang siap dengan perintah Tuhan, seharusnya demikianlah respon bangsa Israel dengan perintah Tuhan untuk hidup kudus dengan menyembah hanya kepada Allah Yahweh.

\section{Tuhan menyatakan kasih-Nya kepada umat-Nya sangat sempurna}

Peran Tuhan dalam kekudusan bangsa Israel di kitab Hosea, nyata dengan perintah Tuhan yang datang kepada Hosea supaya Hosea mengawini Gomer, perempuan sundal. Dalam point ini mau menyatakan bahwa wujud kasih Tuhan yang sangat melimpah bagi bangsa Israel. Sangat sudah tidak terhitung bangsa Israel menyakiti hati Tuhan, baik dari level raja, imam dan umat, namun Tuhan tetap menyatakan hatinya bagi bangsa Israel. Kasih yang diwujudkan adalah dengan mengirim hakim-hakim, raja-raja, nabi-nabi dan bangkitnya keturunan-keturunan imam yang menjadi pendamping kehidupan bangsa Israel. Justru yang terjadi, ketika pemimpin mereka mati, mereka kembali jatuh dalam dosa dengan melanggaran kekudusan Tuhan. Kisah kasih Tuhan yang nyata dalam kehidupan bangsa Israel tergambar dari kehidupan Hosea sebagai 
pribadi yang benar, namun dengan sikap hati yang baik rela mengambil perempuan sundal yaitu Gomer yang sudah bergelimpangan dengan dosa, kotor, menjijikkan dan hidup tidak kudus lagi. Ini sebagai teguran bagi bangsa Israel supaya mereka sadar, bahwa mereka yang telah menjijikkan, dosa, kotor karena penyembahan berhala, mereka masih diterima dengan kasih Allah yang tak terbatas. Ratusan tahun terjadi, Allah yang suci dan kudus, tetap menunjukkan kasih-Nya kepada bangsa Israel yang senantiasa jatuh bangun dalam dosa, namun tetap disapa, tetap diangkat, tetap dipulihkan dan banyak janji-janji Tuhan yang dinyatakan. Ini adalah kemurnian dan ketulusan kasih Tuhan kepada bangsa-Nya.

\section{Tuhan melimpahkan anugerah sebagai dasar kehidupan umat-Nya}

Anugerah adalah sesuatu yang sebetulnya tidak layak untuk diterima tapi diberikan. Peristiwa Hosea mengawini Gomer merupakan bukti sebuah anugerah. Di mana ini menjadi gambaran peran Allah yang menyatakan bahwa Hosea yang selayaknya bisa mendapatkan wanita jauh lebih baik dari Gomer, namun siap mengambil Gomer yang memiliki latar belakang hidup yang tidak baik, bahkan ketika diambil oleh Hosea, Gomer dalam kondisi sangat tidak layak. Gomer adalah gambaran bangsa Israel yang hidup dalam dosa, tidak kudus dan jauh dari Tuhan, namun diambil Allah untuk dilayakkan kembali. Ini sebuah anugerah yang luar biasa. Anugerah merupakan dasar kehidupan. Ketika dapat memahami bahwa bangsa Israel mendapatkan anugerah, seharusnya membuat mereka mengerti arti sebuah kasih yang sangat besar.

Limpahan anugerah atau kasih karunia Tuhan kepada umat-Nya membuat bangsa Israel melihat bahwa Allah sebetulnya tidak pernah meninggalkan umat-Nya. Allah selalu memperhatikan setiap kehidupan bangsa-Nya. Bayangkan ratusan tahun bangsa ini menyakiti hati Tuhan. Sama seperti orang tua yang selalu dibuat sakit hatinya oleh perbuatan anaknya yang tidak sadar bahwa dia bisa ada karena keberadaan orang tua. Dengan gambaran kehidupan Hosea dan Gomer, bisa dilihat betapa anugerah yang senantiasa dialami bangsa Israel.

\section{Tuhan menantikan pertobatan menjadi kunci pemulihan umat-Nya}

Tuhan selalu senang dengan pertobatan. Pertobatan yang membuat Tuhan senantiasa menyatakan janji-janji-Nya dengan dahsyat dalam kehidupan bangsa Israel. Sebetulnya dari kehidupan Hosea dan Gomer serta anak-anak yang dilahirkan dari keluarga mereka, sangat kelihatan bahwa Allah sudah menolak bangsa Israel, sebab mereka hidup tidak kudus (Hos. 2:122). Namun Allah tetap menerima bangsa Israel, jika mereka bertobat dan berbalik dari jalanjalan mereka yang jahat. Memang yang juga disoroti Tuhan adalah kehidupan imam yang tidak setia dan pemimpin-pemimpin Israel yang melakukan roh perzinahan (Hos. 4 dan 5). Akhirnya Israel mengalami pembuangan serta hidup dalam kemerosotan moral serta rohani yang sangat dalam. Namun sekali lagi kadang Allah melihat pertobatan bangsa yang pura (Hos. 5:15-6:6). Bahkan ada suku yang tidak mau bertobat seperti Efraim (Hos. 6:7-7:2). Dan akhirnya penghukuman Tuhan harus dialami bangsa Israel dengan dibuang ke Asyur dan Babel, serta mengalami kehancuran (Manakutty et al., 2016).

Tuhan tetap dengan sabar menantikan pertobatan dari bangsa Israel. Pertobatan bangsa Israel membawa sebuah perjanjian. Pertobatan dan janji menjadi ikatan yang menyatu yang tidak dapat dipisahkan (Hos. 14:2-9). Pertobatan membawa pemulihan, pertobatan membawa berkat, pertobatan membawa perlindungan. Hosea menerima Gomer apa adanya. Kekudusan mengakibatkan sebuah pertobatan.(Maiaweng, 2014) Demikian juga Allah menerima Israel apa adanya jika mereka bertobat dan berbalik dari segala jalan yang jahat serta hidup dalam kebenaran sesuai Taurat Tuhan. Tuhan mengasihi bangsa Israel dan terus menantikan hal-hal ajaib terjadi dalam hidup bangsa Israel. 


\section{Refleksi Teologis Kitab Hosea Tentang Peran Tuhan}

\section{Terhadap Kekudusan bagi Orang Percaya Masa Kini}

Kekudusan bagian terpenting dalam membangun hubungan antara Allah dan manusia. Allah yang kudus hanya bisa berkomunikasi dengan manusia yang kudus, karena ini salah satu buah Roh Kudus (Putra, 2019). Kehidupan manusia memang sudah hancur karena dosa. Namun ketika manusia melakukan kebenaran Firman-Nya, Allah tetap hadir untuk berbicara kepada umat-Nya. Yang terjadi justru sangat menyedihkan, bahwa manusia hidup tidak sesuai dengan kebenaran Firman Tuhan dan memilih mengikuti kehendak pribadi serta cara berpikirnya yang duniawi. Beberapa hal yang membuat hidup manusia tidak dalam kekudusan yaitu penyembahan berhala, menduakan Tuhan, iri hati, kekecewaan, kesombongan, fitnah, perseteruan, roh pemecah, kepentingan diri sendiri, perselisihan, kecemaran dan hawa hafsu. Kedagingan akan membuat manusia melakukan segala sesuatu sesuai dengan apa yang dipandang baik. Kejadian 3 menjadi titik awal manusia jatuh dalam dosa dan melanggar kekudusan Tuhan (Manafe, 2017). Segala sesuatu yang berhubungan dengan dosa adalah melanggar kekudusan Tuhan. Tidak terlepas dengan orang percaya. Mereka sudah menjadi orang Kristen, namun tidak sedikit yang tetap hidup dalam kedagingan atau manusia lama. Inilah yang mengakibatkan hubungan Allah dengan orang percaya menjadi terputus.

Kasih Tuhan yang luar biasa kepada orang percaya dan umat manusia. Dalam kondisi apapun yang terjadi, jatuh bangun dalam dosa dan melanggar kekudusan Tuhan. Tuhan tetap yang selalu memiliki insiatif untuk hadir dan menjanjikan sebuah pemulihan kepada orang percaya. Seperti janji-janji pemulihan yang Tuhan selalu nyatakan kepada bangsa Israel. Meskipun bangsa Israel sudah beberapa kali hidup dalam penyembahan berhala, melanggar kekudusan Tuhan serta menjauh dari Tuhan. Tapi hati-Nya selalu rindu dekat dengan bangsa pilihan-Nya. Dari kisah Kitab Hosea ini, akan didapatkan beberapa hal yang dapat direflesikan dalam kehidupan orang percaya, tentang peran Tuhan terhadap kekudusan bagi orang percaya, ketika Tuhan menggunakan gambaran keluarga Hosea, Di mana Hosea yang hidup berkenan di hadapan Tuhan, bersedia mengambil Gomer, perempuan sundal itu, untuk menjadi isterinya.

\section{Hidup dalam kekudusan secara mutlak}

Hukum Tuhan tidak ada perubahan. Sekali kekudusan menjadi standar penting kehidupan manusia, selamanya akan terus menjadi point penting. Seperti nyata dalam kebenaran Firman Tuhan, 1 Petrus 1:15-16, "tetapi hendaklah kamu menjadi kudus di dalam seluruh hidupmu sama seperti Dia yang kudus, yang telah memanggil kamu, sebab ada tertulis: Kuduslah kamu, sebab Aku kudus." Tuhan memanggil umat-Nya untuk hidup dalam kekudusan dan hidup dalam kekudusan menjadi bagian keteladanan kehidupan (Talizaro Tafona'o, 2019). Sehingga Keteladan Yesus harusnya memampukan orang percaya menjadi panutan dalam setiap kehidupan yang dijalaninya (Arifianto, 2020c). Namun sering yang terjadi, kedagingan dan keduniawian masih menjadi penghalang paling utama dalam membangun dan mempertahankan hidup kudus. Firman Tuhan berkata, dalam Matius 5:8, "Berbahagialah orang yang suci hatinya, karena mereka akan melihat Allah." Nast ini menyatakan bahwa Yesus sendiri sedang menyatakan bahwa kesucian menjadi standar penting bagi kehidupan manusia. Siapa yang hidupnya kudus maka akan bisa melihat Tuhan, membangun hubungan dengan Tuhan dan merasakan kedamaian. Bangsa Israel menjadi sebuah acuan pembelajaran bagi setiap orang percaya bahwa ketika bangsa Israel hidup dalam ketidakkudusan, hidup mereka mengalami kehancuran. Namun ketika mereka hidup dalam kekudusan, mereka mengalami berkat Tuhan. Sebagai orang percaya, kiranya senantiasa mempertahankan kehidupan kudus karena korban Yesus yang sudah menyucikan dosa. Dan menjadikan setiap orang percaya menjadi pribadi yang dipulihkan. Masalahnya bukan bisa atau tidak bisa, namun sebuah komitmen untuk hidup dalam kekudusan. Sebab ada Roh Kudus yang senantiasa memberikan pertolongan dan Roh Kudus mengajar orang percaya dan turut bekerja untuk menerangi orang percaya.(Purwoto et al., 2020) 
Dan Roh Kudus juga dalam kehidupan orang percaya menuntun kepada seluruh kebenaran (Arifianto \& sumiwi Rachmani, 2020). Kuncinya hidup mau dipenuhi dan dipimpin oleh Roh Kudus. Dan setiap orang percaya ada ditebus oleh Yesus, supaya hidup dalam kekudusan (Supriyadi, 2020).

\section{Taat kepada kebenaran Firman Tuhan}

Mazmur 119:9, "Dengan apakah seorang muda mempertahankan kelakuannya bersih? Dengan menjaganya sesuai dengan firman-Mu” Pemazmur menyatakan hal yang paling penting dalam kehidupan orang percaya, yaitu Firman Tuhan. Firman Tuhan adalah standar atau tuntunan hidup dalam kekudusan. Setiap orang percaya harus memiliki komitmen untuk hidup mentaati kebenaran Firman Tuhan. Ini adalah peran Tuhan yang sangat kuat dengan Firman yang dinyatakan kepada orang percaya. Firman Tuhan adalah bagian yang Tuhan berikan kepada orang percaya, supaya setiap orang percaya mendapatkan tuntunan yang jelas dalam kehidupan untuk tidak menyimpang ke kanan atau ke kiri. Firman Tuhan sangat penting untuk membawa kehidupan setiap orang percaya sesuai dengan hati Tuhan. 2 Timotius 3:16-17, "Segala tulisan yang diilhamkan Allah memang bermanfaat untuk mengajar, untuk menyatakan kesalahan, untuk memperbaiki kelakuan dan untuk mendidik orang dalam kebenaran. Dengan demikian tiap-tiap manusia kepunyaan Allah diperlengkapi untuk setiap perbuatan baik." Rasul Paulus menuliskan ini kepada Timotius dengan mengungkapkan bahwa Kitab Suci menjadi kekuatan yang utuh menuntun hidup Timotius hidup dalam kekudusan Tuhan. Itu sebabnya, ketika seseorang hidup sesuai dengan kebenaran Tuhan, akan membuat hidupnya terus dalam kekudusan. Firman Tuhan selalu berlaku dalam sepanjang zaman kehidupan. Jadi dalam kondisi apapun, Firman Tuhan tidak pernah usah dan menjadi standar yang jelas untuk menjagai orang percaya hidup dalam kekudusan. Ketaatan kepada kebenaran Firman Tuhan menjadikan hidup dalam kemenangan ilahi (Manakutty et al., 2016).

\section{Menghargai kasih Tuhan yang sangat besar}

Kasih Tuhan kepada manusia sangat nyata. Sebab Allah itu kasih. Meskipun jika dilihat sejak zaman Perjanjian Lama sampai Perjanjian Baru, Tuhan selalu didukakan dengan pola pikir dan cara hidup umat manusia. Manusia cenderung hidup sesuai dengan kehendaknya sendiri. Sehingga tidak bisa dipungkiri mereka jatuh bangun dalam duka. Peristiwa Hosea mengawini Gomer, dengan perintah Tuhan, memberikan refleksi bahwa kasih Tuhan yang sangat besar bagi bangsa Israel. Demikian juga jika direnungkan, kasih Allah kepada setiap orang percaya tak terhingga. Sesuai dengan kebenaran Firman Tuhan dalam Ratapan 3:21-23, "Tetapi hal-hal inilah yang kuperhatikan, oleh sebab itu aku akan berharap: Tak berkesudahan kasih setia TUHAN, tak habis-habisnya rahmat-Nya, selalu baru tiap pagi; besar kesetiaan-Mu." Kasih Allah tidak dinilai dengan seberapa hebatnya manusia. Peran Tuhan yang sangat luar biasa ini, menyatakan bahwa kasih Tuhan selalu menjadi point pemulihan kehidupan manusia. Sebuah inisiatif yang selalu datangnya dari Tuhan. Itu sebabnya sebagai orang percaya, refleksi bagi setiap orang percaya yaitu menghargai dengan sungguh kasih Allah dengan sungguh-sungguh untuk menjaga hidup kudus sesuai dengan tuntunan kebenaran Firman Tuhan.

\section{Hidup oleh anugerah Tuhan}

Tuhan sangat berlimpah dengan segala kebaikan. Kebaikan-Nya nyata bukan karena unsure kebaikan manusia. Namun kemurnian kebaikan Allah nyata supaya manusia selalu mendapatkan tempat special di hadapan Allah. Ini yang disebut dengan sebuah anugerah. Anugerah adalah sesuatu yang sebetulnya manusia tidak layak terima, namun diberikan kepada manusia. Sesuatu yang sangat berharga dan diberikan dengan cuma-cuma. Peran Tuhan yang sangat menonjol adalah anugerah-Nya yang dinyatakan dengan salib itu yang menjadi manusia menjadi pribadi berharga. Refleksi bagi setiap orang adalah hidup dalam anugerah-Nya dan dengan tidak menyia-nyiakan kasih karunia-Nya. Ketika mengetahui bahwa penebusan terjadi 
karena anugerah-Nya, hendaknya senantiasa menjaga hidup yang sesuai dengan kebenaran Firman Tuhan. Peran Tuhan yang luar biasa yaitu anugerah-Nya yang berlimpah bagi setiap orang percaya, menjadikan setiap orang percaya harus hidup dalam anugerah-Nya dengan melayani Tuhan dengan sungguh-sungguh, terlebih pelayanan yang dipercayakan adalah kehormatan yang diberikan Tuhan dan dikerjakan dengan kesungguhan sebagai dedikasi orang percaya untuk hidup makin mengasihi Tuhan, (Arifianto, 2020a) serta melakukan kebenaran Firman Tuhan dengan sungguh-sungguh. Kekudusan yang orang percaya terima, karena anugerah-Nya (Marde Christian Stenly Mawikere, 2016). Sebagai pribadi yang mengerti arti sebuah anugerah, maka selalu berpikir bagaimana membalas anugerah atau kasih-Nya yang dahsyat. Bahkan rela memberikan segala hidup bagi kemuliaan nama Tuhan.

\section{Senantiasa hidup dalam pertobatan dengan sungguh}

Hidup dalam kebenaran Tuhan menjadi point penting dalam seluruh kehidupan. Kuncinya ketika memahami bahwa orang percaya hidup karena anugerah-Nya, maka responnya adalah senantiasa hidup dalam pertobatan yang sungguh-sungguh. Jangan sampai hidup dalam pertobatan semu. Pertobatan semu adalah pertobatan yang tidak sungguh-sungguh. Mengaku menjadi orang percaya Yesus, namun pola hidup dan cara pikir masih duniawi dan penuh dengan kedagingan. Ini kekristenan tambal sulam. Yang dirindukan secara utuh dalam kehidupan orang percaya adalah sebuah pertobatan permanen. Pertobatan menjadi setiap orang percaya hidup dipulihkan dengan sempurna. Banyak kisah dalam kebenaran Alkitab, ketika mereka tidak bertobat mengalami kebinasaan. Namun ketika mereka bertobat, maka ada janji Tuhan yang disampaikan. Pertobatan merupakan kunci kehidupan yang membuat hati Tuhan makin mengasihi. Ketika jatuh dalam dosa, melanggar kekudusan Tuhan, segera bangkit, bertobat dan jangan mengulangi lagi perbuatan dosa yang sama, seperti pesan Tuhan Yesus, ketika selesai menyembuhkan orang sakit, selalu berpesan, jangan berbuat dosa lagi. Serta hidup dalam kuasa ilahi. Ketika percaya Yesus sebagai Tuhan dan Juruselamat, maka dengan pertolongan Roh Kudus, senantiasa hidup benar. Dan ketika hidup dalam kekudusan, adalah bukti kehidupan orang percaya yang takut akan Tuhan (Tampasigi \& Maiaweng, 2012). 


\section{KESIMPULAN}

Kitab Hosea menjadi sebuah refleksi khusus dalam kehidupan orang percaya masa kini. Menarik dan unik sekali membicarakan kisah Kitab Hosea dan teologi yang terkandung di dalamnya, sebab memiliki makna yang sangat dalam. Khususnya dalam bagian kehidupan Hosea yang dipakai Tuhan untuk menjadi gambaran hubungan Allah dengan bangsa Israel. Peran Tuhan yang sangat nyata untuk memperlihatkan betapa Allah sangat serius dengan kekudusan. Di mana bangsa Israel mengalami masa sulit karena dalam pembuangan, karena mereka hidup makin jauh dari Tuhan dengan hidup dalam penyembahan berhala bahkan membuat patung-patung berhala untuk disembah. Ini membuat hati Tuhan sakit. Tuhan dengan sengaja mengutus nabi Hosea untuk menyampaikan pesan profetik pertobatan kepada bangsa Israel dan sekaligus menjadikan keluarga Hosea menjadi gambaran pesan profetik Tuhan bagi bangsa Israel. Dan untuk memahami konsep teologi kitab Hosea, maka diberikan pemaparan tentang landasan dasar Kitab Hosea yaitu penulis kitab, tahun penulian kitab, tujuan kitab, latar belakang kitab dan garis besar kitab.

Dari kitab Hosea ini, ditemukan peran Tuhan yang luar biasa bagi rencana Tuhan atas bangsa Israel. Khususnya konteks kekudusan yang menjadi sorotan terpenting bagi Tuhan. Sebab Tuhan sangat tidak kompromi dengan dosa. Dosa inilah yang menjadikan hubungan Allah dan bangsa Israel terputus. Ketidakkudusan bangsa Israel karena penyembahan berhala, menduakan Tuhan dan membuat patung-patung penyembahan, menjadikan Allah membinasakan bangsa Israel. Namun kasih Tuhan sangat luar biasa. Nabi Hosea yang dikirim Tuhan menjadi bagian Allah berbicara kepada bangsa Israel. Tuhan memilih nabi Hosea menyatakan tujuannya bagi bangsa pilihannya yaitu mengawini Gomer, perempuan sundal yang melambangkan kehidupan bangsa Israel yang sudah melakukan persundalan rohani, hidup dalam ketidakkudusan dan jauh dari Tuhan. Peran Tuhan nyata sekali untuk kembali mengangkat kehidupan bangsa Israel, sebagai konsep teologi yang muncul dalam kitab Hosea yaitu Pertama, Tuhan sanggup melakukan banyak hal untuk umat-Nya fokus kepada Taurat-Ny. Kedua,, Tuhan menyatakan kasih-Nya kepada umat-Nya sangat sempurna. Ketiga, Tuhan melimpahkan anugerah sebagai dasar kehidupan umat-Nya. Keempat, Tuhan menantikan pertobatan menjadi kunci pemulihan umat-Nya. Kelima, Tuhan menantikan pertobatan menjadi kunci pemulihan umat-Nya.

Dan setiap peran Tuhan ini dapat dilihat, betapa Allah sangat mengasihi manusia, terutama setiap kita orang percaya. Sehingga lewat konsep teologis yang tertuang dalam kitab Hosea dapat direfleksikan peran Tuhan dalam konsep kekudusan yang nyata dalam kehidupan orang percaya, yaitu : Pertama, Hidup dalam kekudusan secara mutlak, Kedua, taat kepada kebenaran Firman Tuhan. Ketiga, menghargai kasih Tuhan yang sangat besar. Keempat, hidup oleh anugerah Tuhan. Kelima, senantiasa hidup dalam pertobatan dengan sungguh. 


\section{REFERENSI}

Alkitab Hidup Berkelimpahan Life application Study Bible. (2016). Gandum Mas.

Arifianto, Y. A. (2020a). Makna Sosio-Teologis Melayani Menurut Roma 12:7. Jurnal Ilmiah Religiosity Entity Humanity (JIREH), 2(2), 184-197. https://doi.org/10.37364/jireh.v2i2.43

Arifianto, Y. A. (2020b). Pentingnya Pendidikan Kristen dalam Membangun Kerohanian Keluarga di Masa Pandemi Covid-19. Regula Fidei Jurnal Pendidikan Agama Kristen, $5(2)$.

Arifianto, Y. A. (2020c). Studi Deskriptif 1 Timotius 4:1-16 tentang Pelayan Kristus yang Baik. JURNAL TEOLOGI RAHMAT, 6(1), 66-77.

Arifianto, Y. A., \& sumiwi Rachmani, A. (2020). Peran Roh Kudus dalam Menuntun Orang Percaya kepada Seluruh Kebenaran Berdasarkan Yohanes 16 : 13. Jurnal Diegesis, 3(1), 112.

Darius, D., \& Panggarra, R. (2013). Konsep Manusia Baru Berdasarkan Perspektif Paulus Dalam Efesus 4:17-32 Dan Implementasinya Dalam Kehidupan Orang Percaya. Jurnal Jaffray. https://doi.org/10.25278/jj71.v11i2.80

Hutagalung, R. C. (2019). Konsep Teologis Perempuan Sundal di dalam Kitab Hosea. PASCA : Jurnal Teologi Dan Pendidikan Agama Kristen. https://doi.org/10.46494/psc.v15i2.55

Lele, A. F., \& Panggarra, R. (2015). Makna Tujuh Ungkapan Yesus Di Salib Bagi Orang Percaya. Jurnal Jaffray, 13(2), 285-316. https://doi.org/10.25278/jj71.v13i2.181

Maiaweng, P. C. D. (2014). Diutus Untuk Menghasilkan umat yang Kudus:Eksposisi Yesaya 6:1-13. Jurnal Jaffray. https://doi.org/10.25278/jj71.v12i1.30

Manafe, Y. Y. (2017). Pengajaran Paulus Tentang Hamba Dosa Dan Hamba Kebenaran Menurut Roma 6: 17-18, Sebagai Upaya Pemurnian Iman Orang Kristen. Sejarah Artikel.

Manakutty, Y. R., Kunci, K., Ketaatan, :, Karunia, K., Hukum Volume, D., \& Nomor, I. |. (2016). Ketaatan dan Kasih Karunia versus Hukum Dalam Kitab Hakim-Hakim dan Relevansinya bagi Pendidikan Agama Kristen. In ejournal.uki.ac.id.

Marbun, P. (2020). Konsep Dosa dalam Perjanjian Lama dan Hubungannya dengan Konsep Perjanjian. CARAKA: Jurnal Teologi Biblika Dan Praktika.

https://doi.org/10.46348/car.v1i1.9

Marde Christian Stenly Mawikere. (2016). Pandangan Teologi Reformed Mengenai Doktrin Pengudusan dan Relevansinya Pada Masa Kini. In JURNAL JAFFRAY.

Natar, A. N. (2016). Penggunaan Metafora Tubuh Perempuan dalam Kitab Hosea. Jurnal Ledalero. https://doi.org/10.31385/j1.v15i1.33.134-149

Purwoto, P., Budiyana, H., \& Arifianto, Y. A. (2020). Landasan Teologis Pendidikan Kristen dalam Perjanjian Baru dan Relevansinya bagi Pendidikan Kristen Masa Kini. 
DIDAKTIKOS: Jurnal Pendidikan Agama Kristen, 3(1), 34-48.

Putra, A. M. (2019). Kebijaksanaan Sebagai Karunia Roh Kudus Makna Dan Buahnya Bagi Hidup Seorang Kristiani. Jurnal Teologi Amreta.

Setio, R. (2017). Menafsir Metafora Dalam Kitab Hosea: Historis Kritis, Feminis, dan Ideologis. GEMA TEOLOGIKA. https://doi.org/10.21460/gema.2017.22.292

Simbawa, J. (2010). Peran Gereja terhadap Kaum LGBT. BPK Gunung Mulia.

Sudarman, S. (2017). Identitas dan Karakteristik Nab-Nabi Israel dalam Perjanjian Lama. KALAM. https://doi.org/10.24042/klm.v6i2.408

Supriyadi, A. (2020). Dipanggil Kepada Kekudusan. JPAK: Jurnal Pendidikan Agama Katolik. https://doi.org/10.34150/jpak.v20i1.251

Talizaro Tafona'o. (2019). Kepribadian Guru Kristen dalam Prespektif 1 Timotius 4:11-16| Tafona'o | Evangelikal: Jurnal Teologi Injili dan Pembinaan Warga Jemaat. Evangelikal: Jurnal Teologi Injili Dan Pembinaan Warga Jemaat Volume 3, Nomor 1.

Tampasigi, R., \& Maiaweng, P. C. D. (2012). Tinjauan Teologis Tentang Takut Akan Tuhan Berdasarkan Kitab Amsal Dan Implementasinya Dalam Hidup Kekristenan. Jurnal Jaffray, 10(1), 118-147.

Tarpin. (2010). Pandangan Kristen Tentang Dosa: Asal Muasal dan Cara Menebusnya. Jurnal Ushuluddin.

Zaluchu, S. E. (2020). Strategi Penelitian Kualitatif dan Kuantitatif Di Dalam Penelitian Agama. Evangelikal: Jurnal Teologi Injili Dan Pembinaan Warga Jemaat, 4(1), 28-38.

https://doi.org/10.46445/ejti.v4i1.167 